\title{
The Nostalgia of Jon Stewart: The Looming Extinction of Journalism
}

\author{
James C. Smoot
}

In the last several years considerable attention has been paid to "fake news" comedy television programming both by journalists and academics. The Daily Show with Jon Stewart (TDS) has drawn the most attention with The New York Times seriously asking the question in 2008: "Is Jon Stewart the most trusted man in America?"[1] The comedian Stewart is taken seriously enough by broadcast journalists to have been awarded two Peabody Awards for broadcast journalistic excellence for presidential campaign coverage in 2000 and 2004. While Stewart insists that he is a comedian only remarking at the award's ceremony that one of the "legitimate" nominees such as 60 Minutes ought to investigate how a fake news program beat them out for the award (Warner 2007:23).

It is not exactly a secret that the boundary between news programming and entertainment programming became blurred decades ago with the advent of "infotainment" in local television news programming in the 1980s where soft, "human interest," stories or fluff began displacing hard news so that a story of a fatal apartment building fire could be juxtaposed with a story about a local baseball player's charity work. "Dumbing down" is a term used by elites for this process as if there were some earlier day where there was a distinct line between news and entertainment. This is a mirage. Television news was tainted by theatrics even in its "golden age."

Before The New York Times asked its question, the title of The Most Trusted Man in Television had been the legendary Walter Cronkite of CBS. Journalist John Nichols (2009) describes Cronkite as "the most serious of serious journalists". Cronkite was instrumental in shaping the new medium of television into its current form, image driven, reducing events without footage to sound bites as the logic of the new medium developed. In an obituary for Cronkite published in The Guardian, Harold Jackson (2009) wrote, "Television, as Marshall McLuhan shrewdly observed, itself became the message and Cronkite was one of those who failed to resist the trend." An obituary in The New York Times said that it wasn't Cronkite's admirable journalistic credentials that made him outstanding but rather his appearance and his journalistic props:

Mr. Cronkite, who sat at a desk next to a typewriter in what at least seemed like a bustling newsroom, would fiddle with his earpiece, move his chair and glance down at his notes; he looked like a kindly newspaper editor interrupted in the middle of a big news day, busy, of course, but never too busy to explain the latest developments to out-of-town visitors. (Stanley 2009)

The operative word here is "seemed." While Cronkite did function as CBS News managing editor, his on-screen presentation was pure theater. Cronkite did not just report the news - he was the news. When Cronkite announced in a 1968 editorial segment that the Vietnam War was lost in the wake of the Tet Offensive, President Lyndon Johnson is reported to have said: 'If I've lost Cronkite, I've lost Middle America." [2] Over the years the format of news theater Cronkite and other's invented developed its logic to the point where the personalities, punditry, props, and theatrical form came to totally eclipse content in the bizarre world of 24-hour pseudo-events with dazzling computer graphics the feeds off of itself more than it feeds off the world on which it is supposed to be reporting. This "news" increasingly resembles Baudrillard's concept of hyperreality, where the generation of representations or models of reality no longer have an origin, or referent in the world and this hyperreal simulation comes to substitute for reality itself.

Much of the discussion of Jon Stewart and "fake" parody news programming misses the point that the 
television news was always fake, always staged. The claim made by Geoffrey Baym that fake news is a new form of journalism deserves some attention. The Daily Show can be better understood not as "fake news" but as an alternative journalism, one that uses satire to interrogate power, parody to critique contemporary news, and dialogue to enact a model of deliberative democracy (Baym 2005:261).

In this article I will critically analyze Baym's thesis. As much as I would like to trumpet the revolution led by Jon Stewart and fake news, Baym's thesis fails on key points. While TDS may indeed be an example of a new form of journalism, it suffers from the same ills that afflict the commodity form it mimics and legitimizes, perverting the news rather than subverting it. Habermas "Public Sphere" arises in this discussion continuously, and for obvious reasons. Debeljak describes the bourgeois public sphere as a "space for a continuous rational-critical debate" where public opinion is formed through discussion and access is guaranteed to all citizens (1998:81). The public sphere is a space between market and state where individuals can publically deliberate and form opinions that will become the basis for democratic action. Already built in to this is the problem of who constitutes a citizen, whose opinion is given the podium. This is the "gatekeeping" function about which more will be said later.

There are specific difficulties that fake news has in engaging in dialogue with power, much less interrogating it, most salient of which is Stewart only engages the simulacrum of power, not power itself. It is not so much an expansion of journalism, but rather a nostalgia for a journalism that never really was on the brink of its extinction. Finally, the laughter engendered by fake news satire and parody is far from the "ambivalent" carnival laughter Bakhtin describes -- a laughter that is regenerative as well as destructive (Bakhtin 1968). As satire, the parody masks a polemical subtext which makes TDS less fake news as it is anti news (i.e. it functions as the negation of the news).

\section{Vukojebina}

I wrote the article on Jon Stewart and fake news not having watched the program on Comedy Central's cable channel for more than eight years. Particularly when the Iraq war was in its nastiest days, I would watch it streaming from the Comedy Central website for some insane relief from insanity. The scholarly articles and some of the books were also obtained through digital transmission from outside Slovenia where I live. In early 2008 I participated in a symposium on art and politics at the faculty of social sciences in Ljubljana presenting this desperate political comedy to an audience who had absolutely no experience of it.

Not so long ago this just would not have been possible. Slovenia has one of the most rural populations in Europe, and its capital, Ljubljana isn't exactly a cultural Mecca, its inhabitants generally abandoning it at weekends. In eastern village where I live, urban culture is entirely absent. Yet I have become a devoted fan of shows like The Wire that I have never seen on television. In this ancient village house with inadequate heating and a shocking sewage disposal system (I flush directly into the creek) I have a 10 mbts broadband connection, a bizarre intrusion into Vukojebina.

That's what I call my house. Vukojebina loosely translates to "the middle of nowhere," but literally from Serbian it means "the place where the wolves fuck." Bucolic isolation in a mountain village of a few hundred, a place where the broadcast television appears to get two channels; the ski jumping channel and the bad Balkan music video channel. I badly needed rescue from the idiocy of rural life.

Up the digital pipe come the supermoveable cultural commodities of American urban culture. I have four computers in this tiny house all networked running Linux and several terabytes of media on hard disks. Inside this house it is all urban cosmopolitan, a digital bubble of American culture, while right outside these walls is rural Slovenia, an entirely alien place. Somewhere very near to where I sit right now is the boundary between the simulation and incomprehensible reality.

Marshall McLuhan wrote made the observation that electronic media accelerated time and collapsed space. People aren't where they are any more, but always elsewhere. It definitely was not my to move here and live in a digital bubble of there, a situation has developed where I know more about what is going on in Los Angeles than in Ljubljana. Slovenia just doesn't produce enough accessible media for a foreigner to situate him or herself here, no English news services, few available literary translations, and very limited film and television production.

The crazy thing is that as a high school teacher I find it very easy to talk about this nether culture with my students, this disembodied American which exists in the online world. Young Slovenes are avid internet pirates, and they really have no choice as there are no legitimate ways of getting most films and television programs here. American cultural commodities are what is available. I use South Park and Family Guy cartoons in class to teach elements of satire, parody and narrative, programs that are only available through downloads.

Long ago I lived in Taiwan and from time to time I would go to the cinema to see American films. Leaving the cinema and walking back out into the noises, sights, and smells of a Chinese city always came as a shock. When I leave these little electronic bubbles here in Slovenia, I get the same shock except that the bubble is now the house. 
So the perpetual question: where the hell am I? The postmodern dissolution of cultural, even geographic boundaries facilitated by internet communications definitely has advantages in bringing things that are distant intimately close. But at the same time it can make what is intimately close incredibly distant. Hence vukojebina, the inhabited no place.

\section{Fake News}

“The spectacle," writes Guy Debord (2002), "is not a collection of images; it is a social relation between people that is mediated by images" (p. 7). The primary target of TDS' satire is the hype and image pollution in the "news" from which TDS draws its raw material. Warner 2007 writes that The Daily Show uses culture jamming techniques derived from Debord and the Situationists, particularly détournement, a "turning" that displaces the expected with a subversive reversal. Perhaps the funniest and most effective segment of The Daily Show is the opening monologue/ bulletin segment where Stewart deconstructs the top stories from the 24-hour news cycle format. Parodying a news anchor Stewart sits at a desk while clips are shown on a screen over his right shoulder. But the selection of clips and Stewart's commentary on (or interaction with) these clips is incongruous. Frequently clips are ripped out of their original context and set against each other: the juxtaposition revealing the manipulative agenda of political branding strategies (Warner 2007). Another strategy is choosing from the video feeds clips that do not fit the cogent, eightsecond sound bite format but rather reveal bad grammar, hesitation, contradiction and apparent confusion on the part of the speaker. Stewart often interrupts these clips to ask questions, which are then followed by another outof-context clip that provides an answer. Simple juxtaposition of clips out of time, as in the Bush vs. Bush debate between 2000 Governor Bush and 2003 President Bush where Stewart plays the straight faced moderator while "the Bushes" contradict each other is a brilliant act of détournement, turning the image against itself to reveal hypocrisy.

Lauren Feldman argues that TDS was one of the few critical voices on television after the September 11, 2001 terrorist attacks while the news media marched in lockstep with the Bush administration into war in Iraq. Citing many journalistic sources, she states that it is possible that The Daily Show broke the Cheney-Halliburton story, where the Vice President's former company was given lucrative postwar contracts in a "no bid" tender (Feldman 2005). Actually breaking a story is a highly sought trophy in American journalism, but this claim needs to be scrutinized carefully. The fake news The Daily Show employs no reporters and is entirely parasitic on the "real" news for its information. Much of the March 25, 2003 episode was devoted to the Halliburton contract. In a faux suspense announcement of the winner of the contract, complete with drum roll, Stewart opens the envelope and finds Halliburton inside. Stewart simply adds up that Cheney was the CEO of the company until he became Vice President, he says "on the bright side I won my office pool, but hearing that makes me feel that the government has just taken a shit [bleeped out] on my chest."'[3] While actual corruption is never explicitly stated, it is assumed in the comic horror to the announcement.

As fake news, argues Warner, Stewart can operate stealthily through his role as Socratic straight man: he is not bound by any code of journalistic ethics. According to Lukacs, journalistic professionalism is the "apogee" of capitalist reification as it is precisely the journalist's subjectivity itself that must be suppressed in order to present "the facts" (Lukacs [1921] 1971:100). The Halliburton story did not require any investigation as the facts were public knowledge. It took the will to do the math and state the conclusion, which The Daily Show achieved in a tragic-comic fashion. In March 2003 the major news media was still bedazzled by the war machine and the theater of war (pun intended). Only later would major news organizations such as the New York Times realize how thoroughly they had been duped by the Bush administration through "leaks" of false information regarding weapons of mass destruction and other rather fanciful fabrications of the "intelligence community." [4]

In this case the fake news, assuming a satirical voice, took the primary function of "real news" when the "real news" failed to state the obvious. Baym states, "Any notion of "fake" news depends upon an equal conception of "real." Fake news necessitates assumptions about some kind of authentic or legitimate set of news practices, ideals that one rarely hears articulated or necessarily sees as evident today" (Baym 2005:261). The Daily Show in its close parody of "real news" in form (it never deviates from established journalism in form) draws attention through its satire to the corruption of news practices, not to the broadcast news format itself. This is not détournement in the sense that DeBord had in mind. The purpose of détournement is the negation of culture, a violent subversion of the existing order (Debord 2002:114), which is clearly not what The Daily Show is doing. 
Nothing on The Daily Show deals a structural critique to the broadcast news. Aaron McKain (2005) argues that TDS appropriations of news media forms may "... actually instill faith in the host, reifying conventional News as an "ideal or norm" (p. 416). While it may puncture and deflate aspects of the news as spectacle, such as the odious "stand up" shots where a news reporter reads a prepared script on the scene (e.g. in front of the White House), it does not deflate the news itself. The message appears to be one of reform rather than revolution that the news has become corrupted and needs to get back to its function of speaking the truth.

Perhaps the most serious criticism of news reporting both broadcast and print is editorial "gatekeeping," most clearly articulated by Noam Chomsky in his book Manufacturing Consent. The gatekeeping function filters the newsworthy from the not newsworthy, and how events will be reported and represented. As a parasite, The Daily Show is dependent on the news gatekeeping even when satirizing it (McKain 2005:418). It cannot add to the content or expand it in any way. Despite its scathing criticism of the news, the Daily Show's parody functions to legitimize the news and gatekeeping.

\section{| Dialogue and Monologue}

Baym claims that The Daily Show is "dialogic in the Bakhtinian sense, playing of multiple voices against each other in a discursive exchange that forces the original statement into revealing contexts" (Baym 2005:266). In contrast to the mainstream news, where the sound bite and anchor's voice constitute a monologue, Stewart's perversion of the news anchor into the voice of the enraged citizen calls into question the legitimacy of the original, often through his catchphrase, "are you insane?" What is at issue is whether this dialogue is between two languages or is within a single, hermetic language(i.e., internally dialogized). In that case, according to Bakhtin (1981), the discourse can never be fundamental: "It is merely a game, a tempest in a teapot" (p. 325). Polemic is the sort of discourse produced by this game.

The second sort of dialogue is basically trivial, but Bakhtin's conception of dialogue is directly relevent to the gatekeeping function discussed in the previous section. For Bakhtin (1981) languages are stratified socio-ideologically both in what we would call dialects as well as jargons, so at any given moment a language is heteroglossic (p. 271). A single person can speak many "languages" in this sense, but they don't necessarily engage in dialogue with each other even though they may embody conflicting ideological systems. Bahktin gives examples including the "worlds" of prayer, song, labor, everyday life, and the world of the authorities (ibid 296). Potential conversations between languages can only occur in a zone of dialogic contact (ibid 45).

The close parody of The Daily Show is dual voiced and dialogic as is all parody since the words used have a second, critical set of meanings that usually operate beneath the surface, for instance in the gross exaggeration of the star reporter played by Steven Colbert. The perversion of journalistic discourse to unacceptable levels does unmask the untruth in the original, turns it into a image in Bakhtin's terms, but it does not subvert journalistic discourse itself. The second voice in the parody dialogue speaks the same language of the first. So The Daily Show parody masks a potent polemic uttered sotto voce. The dialogue between the pompous language of the news either through fake reporters or through video clips is the standard straight man - comic routine of Abbot and Costello applied to news. Stewart, the host and man behind the desk, plays the straight man acting with the voice of the outraged citizen.

It is in this sense that Stewart interrogates power, as straight man to comic. A standard routine is Stewart interacting with carefully edited video clips of powerful figures such as President George Bush. Stewart reacts and asks questions then another clip is played in answer. The out of context video clips and Stewart's "dialogue" with them reveals their vacuous rhetorical strategies of deception and misdirection -- and is very effective. It is hard to see how having the simulacrum of George Bush playing the bumbling laugh getter to Stewart's devious Abbot is any real engagement of power. It is the image of power, not power itself that is being interrogated. What's more is that as the parasite, it is image of the image of power converted into yet another image through parody. One can further extend the procession of these images to the television screen on which the viewer watches The Daily Show.

While powerful political figures such as John McCain have appeared as guests for the interview segment on the show, they are seldom "interrogated." The fact that Stewart does not grill his interviewees raised vocal criticism from Tucker Carlson, the co-host of CNN's debate program Crossfire. While the interview segment takes the form of the late night talk show, such as Letterman, the interviews are seldom mere fluff. "In pace of reductionist polemics, Stewart's politically oriented interviews pursue thoughtful discussion of national problems. The goal of the 
discussion is not the tearing down of the "other" side (although Stewart never hides his own political preferences) or some banal prediction of the shape of things to come, but rather an effort to gain greater understanding of national problems and their potential solutions" (Baym 2005: 271). Often these interviews segments become news themselves as when Senator John Edwards announced his candidacy for president on the show. These interviews on a fake news program have in turn created many news stories for the "real" news, but comedians can also create pseudo-events (McKain gives the example of the Dean scream) that are re-remediated into news. In this sense the news is parasitic on fake news (or other comedy programs) for stories.

\section{Laughter}

The Daily Show is funny, often achingly so. As political satire, it has no equal in contemporary America. The show runs four nights a week, and as a parasite on the news, writing the evening's script is a feverish process beginning early in the morning with a review of media from the previous day. According to Jon Stewart, the writers are looking for "those types of stories that can, almost like the guy in The Green Mile — the Stephen King story and film in which a character has the apparent ability to heal others by drawing out their ailments and pain — "suck in all the toxins and allow you to do something with it that is palatable" (Kakutani 2008). Like in real news rooms deadlines can be ferocious with the shows complex graphics often being finished shortly before taping (Hanas 2008). Making the tragic comic requires sensitivity and dexterity, using plays on words, "Mess 'O Potamia" for the Iraq war, and "Indecision 2000, 2004, 2008 and so forth" for the political campaign coverage.

Stewart's quote in the above paragraph suggests he sees the show as having a palliative or healing role. Justine Suchard (2008), using Adorno, argues Stewart employs "critical laughter" seeing The Daily Show as being critically effective in the post 9/11 Iraq war moment. Employing Adorno, the gloomiest of theorists, to make an argument for critical laughter may seem a stretch, particularly embodied in a culture industry commodity such as The Daily Show. In Dialectic of the Enlightenment, Adorno and Horkheimer, accuse the culture industry of making "laughter the instrument of the fraud practiced on happiness" (Adorno and Horkheimer [1944]1997:140). Yet she argues that there is a "serious laughter" that comes in the form of irony. Unlike parody, which Adorno found as a form of domination, irony is "a form of self critique that expresses the inexpressible without diminishing it" (quoted in Schuchard 2008:6). In Minima Moralia Adorno writes: "Irony convicts its object by presenting it as what it purports to be; and without passing judgement, as if leaving a blank for the observing subject, measures it against its beingin-itself. It shows up the negative by confronting the positive with its own claim to positivity. It cancels itself out the moment it adds a word of interpretation. In this it presupposes the idea of self-evident, originally of social resonance" (Adorno 2005:210). Irony only works when it is not interpreted but recognized, something Stewart does through careful placement of out of context clips. Yet there is another caveat Adorno makes, "He who has laughter on his side needs no proof" (ibid). In the post 9/11 climate The Daily Show manages to critique the uncritical media consensus by showing it, perhaps as Stewart says by providing catharsis, a release of tension, that kind of laughter that "occurs when some fear passes" (Adorno and Horkeimer [1944] 1997 ibid). "Conciliatory laughter is heard as the echo of an escape from power; the wrong kind overcomes fear by capitulating to the forces which are to be feared" (ibid). It's arguable that the TDS comedy engenders the first kind of laughter, but this is a desperate laughter of escape, not fighting, fearless laughter.

Another defense of laughter as the critical force of The Daily Show comes from Warner. Citing Bakhtin, he states, "If we can laugh at it, we can examine it, evaluate it, even critique it. Laughter has the power to disrupt any analytical paralysis engendered by fear" (Warner 2007:33). If anyone is the great proponent of the liberating power of laughter it is Mikhail Bakhtin. His book Rabelais and His World is not just about carnival laughter as fun (actually the word "fun" doesn't even appear in the book) but that it has revolutionary power to remake the world. In the earlier section I discussed Bakhtin's ideas on heteroglossia and how the dialogue in The Daily- Show doesn't quite register in the zone of dialogic contact because the dialogue has the form of a polemic, the dual voice of the parody is within the language of journalism rather than between languages. Similarly, Bakhtin's liberating laughter is not the sort of laughter engendered by The Daily Show.

Both parody and irony, the comic forms discussed in this paper, depend on context for their comic effect. It is well know that British comedy television programs do not cross the Atlantic with the cultural baggage that would make them comic to Americans. The comedy The Office was rewritten for American audiences as showing 
the original was a flop. Comedies heading east across the Atlantic find their baggage already there as a result of the hegemonic power of the American culture industry. Bakhtin in his work on Rabelais suggests that the key to understanding works whose authors intended to be comic has been lost. Old Testament scholar Thomas Thompson argues that The Book of Job can be best understood as an ancient satire on piety, an idea that would prompt enraged protest from many modern Christians and Jews (Thompson 1999). Moreover, the nature of laughter has changed from collective ambivalence of positive and negative forces to just the negative. Central to Bakhtin's understanding of medieval laughter is the concept of the "carnivalesque." While the hedonistic festival of Carnival has persisted to current times, Bakhtin (1968) writes that these are just "the best preserved fragments of an immense, infinitely rich world" (p. 218). Carnival laughter was not in any sense theatrical. "Carnival is not a spectacle seen by the people; they live in it, and everyone participates because its very idea embraces all the people. While carnival lasts, there is no other life outside it" (ibid 7). It is the fusion of subject and object. Carnival is not something you watch; it is something you are inside of subject to its own laws of freedom and "outside of all existing forms of the coercive socioeconomic and political organization, which is suspended for the time of the festivity." It is immediate, sensual, and above all physical (ibid 255).

Parody and travesty in medieval Europe that mocked the liturgy, the mass, and other sacred rituals, yet were at least tolerated, in some cases actually written by ecclesiastical authorities. These parodies did degrade the sacred, but they also had a regenerative function, destruction followed by rebirth. The grotesque realism employed by Rabelais emphasizes the lower stratum of the body, defecation, copulation, conception, pregnancy and birth (ibid 21). This positive aspect, or the key to it, is lost during the Enlightenment according to Bakhtin. Laughter becomes private, individual, trivial and only destructive losing it universal liberating power. "The satirist whose laughter is negative places himself above the object of his mockery, he is opposed to it” (ibid 12). The corrupt, dominating laughter described by Adorno in The Dialectic of the Enlightenment is not laughter at all to Bakhtin, but rhetoric, a laughter that does not laugh. True laughter for Bakhtin is laughing with, not laughing at.

It is very difficult to successfully deploy Bakhtin's idea of the carnivalesque to The Daily Show. Besides the destructive, polemical intent of its parodies, it is a nonparticipatory spectacle, a commodity one consumes rather than becoming one of its creators. It is the rhetorical negation of the news despite offering itself up as the hysterical voice of reason. While Stewart routinely transgresses news practices in order to point out its failure to function as a source of information, he seldom transgresses the boundaries of "good taste" beyond the occasional expletive and innuendo. The grotesque is absent, as is the regenerative power of laughter, which would be truly subversive.

\section{The Nostalgia of Jon Stewart}

Carnivalesque revolutionary anarchy is not the aim of The Daily Show. I believe it when he insists he is not a journalist, nor is he attempting to create a new hybrid form of journalism. His on-screen persona of the everyman trying to make sense of the gibberish that constitutes political news is an attempt to enact what the citizen should be in deliberative democracy, skeptical, critical, attentive, and interested in rational discussion. His affected disbelief and bewilderment isn't just for laughs; it is also a demonstration of how a citizen should react to the news media spectacle. In other words, Jon Stewart is not the star of the spectacle, but, like the rest of us, one of its victims.

His assumption of vox populi is most clear on his 2004 appearance on CNN's debate program Crossfire already mentioned above. Crossfire is the epitome of the split-screen shouting matches that are called debate programs, and a frequent target of Stewart's on-screen ire. Stewart's appearance on Crossfire, and his masterful performance reveals a lot of what The Daily Show does, and what Stewart's real agenda is. Crossfire was canceled a few months after Stewart's appearance, and the president of CNN cited Stewart's criticism as one of the reasons for its cancellation, once again the fake news influencing the real news.

After a bit of obligatory banter, Stewart maneuvers the rhetorical situation to being about Crossfire and its hosts rather than about himself. He says he made a special effort to come and tell them that the show is not so much bad, but is hurting America.[5] He ask them to stop, then pleads, "stop, stop, stop hurting America." Beluga and Carlson struggle to regain the initiative, but then Stewart pleads with them to "come work for us, because we, as the people..." At which point Carlson interrupts with an attempt at humor? "How much do you pay?" Carlson has blundered into a trap as the joke puts him outside the people legitimating Stewart's assumption of vox populi. He continues in this voice, "we need your help. Right now you are helping the politicians and the corporations. And we're left out there 
to mow our lawns."

Carlson and Beluga are masters of controlling the conversation, guiding it into the format "debate" path, but Stewart refuses to rise to the bait, responding to an accusation that he soft balled Democratic Presidential nominee John Kerry on his show, Stewart answers "I also gave him a backrub." Stewart will not play the game and even refuses to be funny when Carlson chides him for being so serious saying "I'm not going to be your monkey." Responding to Belgala's assertion that Crossfire is a debate show, Stewart responds that it is "like pro-wrestling is a show about athletic competition." It's not debate, but theater. "If your idea of confronting me is that I don't ask hard-hitting enough questions, we're in bad shape fellows." And later, "You're on CNN. The show that leads into me is puppets making prank phone calls. What's wrong with you?” Constantly keeping Begala and Carlson on the back foot, Stewart throws his sharpest barb, "you have a responsibility to the public discourse, and you fail miserably."

Stewart's claims to be just a comedian are disingenuous for all the reasons noted above, but even though the boundaries between comedy and news are long gone, technically they are still there. This technicality enables Stewart to be the outsider, the excluded public in the rhetorical situation he successfully hijacks. The role assumed is that of the gadfly, the pest, insisting that real journalists do their jobs and reinstall the boundaries between news and entertainment.

It is clear from this interview that Jon Stewart is in no sense a revolutionary. His agenda is reform; moreover, it is a return to the "golden age" of journalism. This is very clear in his book, America (The Book): A Citizen's Guide to Democracy Inaction. The chapter on the media begins thus:

A free and independent press is essential to the health of a functioning democracy. It serves to inform the voting public of matters essential to its well-being. Why they've stopped doing that is a mystery. I mean, 300 camera crews outside the courthouse to see what Kobe Bryant is wearing when the judge sets his hearing date, while false information used to send our country to war goes unchecked? What the fuck happened? (Stewart 2004:133)

Despite the expletives and levity, this is a statement of longing, of nostalgia for the golden age of the republic, when journalism was journalism and not theater.

In the introduction to this paper I discussed Walter Cronkite and the golden age of television news. It was theater then. Anyone who believes that newspapers were immune to the disease of the spectacle should watch Howard Hawks 1940 screwball comedy, His Girl Friday. Competition to sell papers was fierce and reporters and editors resorted to all sorts of skullduggery. Robert Love, writing in The Columbia Journalism Review, points out that fake news has been with us at least since the eighth century. With the advent of mass media in the late nineteenth century, fakery was so commonplace that a taxonomy of fakers' techniques was compiled in 1903 (Love 2007:34). Love reminds us that even then, media was big money dominated by huge corporations like Hearst and Pulitzer the influence of which was enough (in Hearst's case) to push the United States into war with Spain with the slogan, "Remember the Maine!'[6] Even the great doyen of early 20th Century American journalism, H.L. Mencken wrote hoax stories passed off as true. Love (2007) writes that hoaxers are historically not comedians, but journalists who write "entertaining stuff that sounds vaguely true, even though it's not, for editors who are usually in on the joke" (p. 36). According to Love, hoaxing infected newsrooms of the day with possibly thousands of hoax stories passed off as the real thing in the period. A hoax differs from a prank when the fakery is not revealed; that is to say, hoaxes are only funny to people in on the joke who laugh derisively when the rubes (readers) fall for it. The contempt that journalists have for their readers is readily apparent to anyone who has ever worked in a newsroom. Recent forgery scandals at The New York Times and The New Republic where journalists entirely fabricated prize winning stories, indicate the persistence of fakery even in the most august of news organizations. The ease that fakes can be passed off as real is indicated by the satirical newspaper, The Onion, still finds its fake copy picked up as the real thing by newspapers around the world.[7]

Nostalgia is widely and rightly criticized for being reactionary and escapist, a turn away from action. Clearly this is not the intention of Stewart's employment of the mythical Republic. To a certain extent nostalgia has been rehabilitated, particularly in post-colonial research as a "necessary resource for those who find their political and social aspirations obliterated by monolithic versions of modernity" (Bonnet 2006:24). This politics of loss plays a key role in Situationist thought. The first thesis from The Society of the Spectacle states: In societies dominated by modern conditions of production, life is presented as an immense accumulation of spectacles. Everything that was directly lived has receded into representation" (Debord 2002). The Situationists set out to reclaim real life from its spectacular obliteration; hence, in order to go forward to the revolution, what has been lost is evoked. The utopian past of deliberative democracy Stewart employs is the vision of the yet to come utopian future. 


\section{The End of Journalism}

One blatantly obvious reason why Baym's thesis that The Daily Show is a new form of journalism fails is Stewart's repeated denials of being a journalist, and his insistence that journalists go back to journalism instead of producing spectacles. While it is the case that the fake news The Daily Show is substantively equivalent to network news broadcasts (Fox, Koloen and Sahin 2007), (i.e., the fake news is equally informative to real news) its parasitic nature prevents it from being more informative. Without real reporters, people who are paid to go out into the grubby real world and ask questions, it can never be more than it is, an attempt at détournement in which it also fails.

From Marshall McLuhan to Douglas Rushkoff, visionaries have seen the potential in electronic media to enhance and achieve deliberative democracy. The current rage over the Internet, social networking sites, "smartphones" that can record audio and video then upload it to the internet has bubbled over into the "old" media where Twitter gossip can form the basis for an entire cycle of 24-hour news spectacle. It is already been noted that The Daily Show re-remediates the gatekeeping of the real news, but participatory model of the "new media" promises to eliminate gatekeeping altogether and enact a true public sphere. A small study of Internet based political groups by Victor Prickard finds their effectiveness and genuine novelty to be at best limited to grass roots organizing for particular issues, rather than discussion which it fragments. He also warns that internet service providers frequently block content and protocols (e.g., Bittorrent) which increasingly limit both the content and the structure of internet models of deliberative democracy. He also finds that "corporate interests increasingly dominate multiple layers of the internet" (Pickard 2008:628).

This vision fails for several reasons, most salient being that it intensifies the spectacle rather than weakening it by taking the spectacle as its source. First, the new media is parasitic on the old media as is The Daily Show. The problem is that the host, the old media, already ill from other causes appears to be in terminal decline from this parasitic infection. In an article entitled, "Does the News Matter To Anyone Anymore?" veteran newspaperman and creator of the television series, The Wire, writes that newsroom staff cuts on The Baltimore Sun mean that the city isn't covered any more. "So in a city where half the adult black males are unemployed, where the unions have been busted, and crime and poverty have overwhelmed one neighborhood after the next, the daily newspaper no longer maintains a poverty beat or a labor beat" (Simon 2008). Other beats, the prison system, even the courthouse remain uncovered, that is to say unmonitored. Already ill because of their careless management, the loss of advertising revenue to the Internet has caused American newspapers to strip their newsrooms even more of the most experienced reporters (the best paid are the first cut) or, shutting down entirely as in the cases of the Seattle Post-Intelligencer and Denver's Rocky Mountain News in 2009. Even The New York Times had to mortgage its Manhattan headquarters building to meet operating costs. If the old media functions poorly and undemocratically through its gatekeeping function, they do pay people to go out into the world and at least try to figure reality out. The new media depends on the old for its facts, and once it is gone, the new media will be bereft of any independent sources of information about the world; it will no longer have any referent. The interactive spectacle will float as pure simulation, the triumph of the object in Baudrillard's (2008) terms.

Another reason why The Daily Show and the new media fail to inflate the public sphere is the phenomenon known as "preaching to the choir." The multiplicity of choices and niche marketing has created a "forum" for every political taste and ideology no matter how crackpot. These are ghettoes of sameness Zigmunt Bauman (2000) describes in the "purified" residential developments in Europe and the United States. While there may be disagreement in these "forums," generally everyone shares the same viewpoint. In newsgroup jargon, someone who enters a thread with the purpose of interjecting an alien point of view is known as a "troll." Boundaries are maintained. The Roman Forum was a physical, crowded marketplace, of immediate physical contact of the type Bakhtin describes as essential for realized freedom. Roman magistrates were given lictors, men armed with clubs, to defend the magistrate and clear the way. In Bakhtin's terms the Forum was a zone of contact, a place of polyglossia where many languages crossed and had to come to terms with each other. The Public Sphere only can function if everyone must listen. There can't be Public Spheres. Deliberative democracy a la Habermas requires a society wide discussion.

\section{Conclusion}

Advertising critic Thomas Frank in his book The Conquest of Cool shows how easily protest and rebellion can 
be commodified and turned against their original intentions. The success of The Daily Show not so much due to being fake news, which it isn't, but rather as being anti-news, and ever so cool. With a rating of two million viewers in 2008, nearly equal to its real news competition, Comedy Central makes a considerable amount of revenue for this popular show. Already real news organizations are borrowing tactics from The Daily Show (Smolkin 2007), so it's conceivable the "real" news can adopt "fake" news tactics and become fake-fake. Parody, as Adorno notes, is hierarchical and can be deployed by anyone, for liberation or domination. Debord avoided parody as a tool of détournement as it maintains rather than unsettling the audience's hold on truth (Harold:192,204). The Daily Show is a commodity in the market, and successful commodities breed imitations. In this sense, freeing parody into news can actually make things worse.

Finally, returning to the Crossfire interview, John Stewart's attack, "Right now you are helping the politicians and the corporations," has the whiff of hypocrisy about it. The Daily Show makes a lot of money for Comedy Central which makes a lot of money for its parent company Viacom whose total revenue for 2009 was reported at $\$ 3.32$ billion. [8] John Stewart too is helping the corporations. Viacom is one of the six giant media corporations that dominate the old media and increasingly the new as well. Viacom also has news operations, and formerly owned CBS. Crossfire runs on CNN owned by the behemoth, Time Warner. So the interview was between two commodities of rival corporations, corporations that were rumored to be in merger negotiations at the end of 2009. As far as fake news and theater go, this was sublime. Rather than escaping the simulation, this is an even higher form of it. Belgala, Colson, and Stewart were present because it suited the interest of actual power, Time Warner and Viacom. Power was not interrogated or present in any visible form other than logos.

It would seem that Stewart, with his assumption of the mantle, "we the people," is playing to the question I began this essay with, "Is Jon Stewart the most Trusted Man in America?" Like Walter Cronkite, he affects to be one of us, our representative, a proxy for the public who speaks for us. He's not. Even in parody there is a truth claim, one that is immediately falsified by the spectacle itself. Cronkite used to close his CBS news broadcast with the statement, "And that's the way it is." The most trusted man in America could get away with such pretention, so should Stewart close The Daily Show with “and that's the way it isn't?”

\section{Endnotes}

1. Michiko Kakutani, "Is Jon Stewart the Most Trusted Man in America?" The New York Times, 15 August 2008. http://www.nytimes.com/2008/08/17/arts/ television/17kaku.html?_r=1\&pagewanted=all

2. Review of Walter Cronkite's memoir, A Reporter's Life,. "Broadcast News," http://www.nytimes.com/ books/97/01/26/reviews/970126.26wickert.html? $\mathrm{r}=1$. Retrieved 29 Jan. 2010

3. March 25, 2003. "Halliburton Wins." http://www. thedailyshow.com/watch/tue-march-25-2003/ halliburton-wins

4. For a reasonably complete account, see Rajiv Chandrasekaran's Imperial Life in the Emerald City: Inside Baghdad's Green Zone, 2006, Bloomsbury Publishing, London.

5. Transcript from CNN. http://transcripts.cnn.com/ TRANSCRIPTS/0410/15/cf.01.html
6. The Maine was a US battleship that mysteriously exploded in Havana harbor 15 February 1898 sinking the ship and killing hundreds of sailors. The forward magazines exploded, but the cause of this explosion has never been determined. Hearst's papers developed a lurid story that a Spanish mine sank the ship to keep the US out of Cuba. Herst offered a \$50,000 reward "For the Detection of the Perpetrator of the Maine Outrage!"

7. In 2009 two newspapers in Bangladesh picked up an Onion that revealed the Apollo Moon landings were faked.

8. Claire Atkinson -- Broadcasting \& Cable, 11/3/2009. Retrieved 31 Jan 2010. http://www.broadcastingcable. com/article/367362-Viacom_Q3_Ad_Revenue_ Falls_4_Decline_Slowing.php 


\section{References}

Adorno, Theodor W. 2005. Minima Moralia: Reflections on a Damaged Life. London: Verso.

Adorno, Theodor W. and Max Horkheimer. [1944] 1997. Dialectic of the Enlightenment. London: Verso..

Bakhtin, Mikhail. 1968. Rabelais and His World. Bloomington, IN: Indiana University Press.

-.1981. The Dialogic Imagination: Four Essays. Austin: University of Texas Press.

Baudrillard, Jean. 1994. Simulacra and Simulation. Ann Arbor: University of Michigan Press.

—. 2008. The Perfect Crime. London: Verso.

Bauman, Zygmunt. 2000. Liquid Modernity. Cambridge: Polity Press.

Baym, Geoffry. 2005. “The Daily Show: Discursive Integration and the Reinvention of Political Journalism." Political Communication 259-276.

Bonnet, Alastair. 2008. "The Nostalgias of Situationist Subversion." Theory, Culture and Society 23-48.

Debeljak, Ales. 1998. Reluctant Modernity. Oxford: Rowman and Littlefield Publishers, Inc..

Debord, Guy. 2002. Society of the Spectacle. London: Rebel Press.

Feldman, Lauren. 2005. “The News about Comedy: Young Audiences, The Daily Show, and Evolving

Notions of Journalism.” Conference Papers 1-29, International Communications Association.

Fox, Julia R., Glory Koloen, and Volkan Sahin. 2007. "No Joke: A Comparison of Substance in The Daily Show with Jon Stewart and Broadcast Network Television Coverage of the 2004 Election Campaign.” 213-227.

Frank, Thomas. 1997. The Conquest of Cool: Business Culture, Counterculture, and the Rise of Hip Consumerism. London: University of Chicago Press.

Hanas, Jim. 2008. "And That's The Way It Isn't." Print October:50-55.
Harold, Christine. 2004. "Pranking Rhetoric: "Culture Jamming" as Media Activism." Critical Studies in Media Communication September 21: 189-211.

Jackson, Harold. 2009. "US Anchorman Walter Cronkite Dies, Aged 92.” The Guardian, July 18.

Kakutani, Michichko. 2008. "Is Jon Stewart the Most Trusted Man in America?” The New York Times, August 15, 2008.

Love, Robert. 2007. "Before Jon Stewart: The Truth about Fake News. Believe it." The Columbia Journalism Review March/ April:33-37.

Lukacs, Georg. [1921] 1971. History and Class Consciousness. Cambridge, Mass.: MIT Press.

McKain, Aaron. 2005. "Not Necessarily Not the News: Gatekeeping, Remediation, and The Daily Show." The Journal of American Culture 8:415-430.

Pickard, Victor W. 2008. "Cooptation and Cooperation: Institutional Exemplars of Democratic Internet Technology." New Media and Society 4:625-645.

Schuchard, Justine. 2008. "Serious Laughter: Adorno, The Daily Show, and the Critical Role of Comedy." National Communication Association 94th Annual Convention.

Simon, David. 2008. "Does the News Matter to Anyone Anymore?” The Washington Post, January 18, 2008.

Smolkin, Rachel. 2007. "What the Mainstream Media Can Learn From Jon Stewart.” American Journalism Review. June/July ed.

Stanley, Alessandra. 2009. "Cronkite's Signature: Approachable Authority." The New York Times, August 18, 2009.

Stewart, John. 2004. America (The Book): A Citizen's Guide to Democracy Inaction. Grand Central Publishing.

Thompson, Thomas L. 1999. The Bible in History: How Writers Create a Past. London: Pimlico.

Warner, Jamie. 2007. "Political Culture Jamming: The Dissident Humor of The Daily Show with Jon Steart." Popular Communications 5(1): 17-36.. 